Brit. Heart J., 1965, 27, 401.

\title{
HÆMODYNAMIC EFFECTS OF OXYGEN IN PATIENTS WITH ACUTE MYOCARDIAL INFARCTION
}

\author{
BY \\ MICHAEL THOMAS, RAOUL MALMCRONA, AND JOHN SHILLINGFORD
}

From the Medical Research Council Cardiovascular Research Group, Department of Medicine, Postgraduate Medical School of London, W.12

Received October 17, 1964

Oxygen is frequently given in the treatment of patients with acute myocardial infarction. The hæmodynamic changes associated with its administration in this condition have not been defined.

The purpose of this study has been to investigate the effect of breathing oxygen on the cardiac output and systemic arterial pressure of patients in the early stages of acute myocardial infarction.

\section{SubJECTS AND MeTHOdS}

Six male patients aged 47 to 72 years were studied on the first and second day of myocardial infarction. In two of these there were additional studies on the sixth and seventh days. In one patient there was only one study on the tenth day. All had unequivocal evidence of acute myocardial infarction as judged by the clinical history and electrocardiograph. The clinical data are given in Table I.

All patients were investigated in a special intensive care unit permanently equipped with apparatus for observation, investigation, and treatment of patients with acute myocardial infarction (Shillingford and Thomas, 1964). Facilities were available for the measurement of cardiac output and intravascular pressures.

After clinical assessment, electrocardiography, and chest radiography were completed, polythene catheters (Intramedic U.S.A. PE60) were inserted percutaneously into the brachial artery and an antecubital vein. The venous catheter was advanced so that the tip lay in the superior vena cava. Heart rates were measured from an electrocardiographic tracing over half-minute periods throughout the study and when cardiac output determinations were made. Cardiac output was measured by a dye dilution technique using Coomassie Blue (I.C.I.) as indicator and recording the curve with a photoelectric earpiece (Cambridge Instrument Co.). The first curve was calibrated by equating the height of the tail of the curve three minutes after injection with the amount of indicator in a central venous or arterial blood sample taken at the same time. Dye was extracted from the plasma and measured by spectrophotometry. Subsequent cardiac outputs were calculated according to the areas of the curves (Gabe, Tuckman, and Shillingford, 1962).

Brachial arterial pressures were measured by strain gauge manometers (P23Gb Statham Transducers Inc.) and recorded on a direct writing system (Devices Ltd). The pressures were measured with reference to a point $5 \mathrm{~cm}$. below the sternal angle. Measurements were made throughout the periods of study and immediately before each cardiac output determination. Pressure flow ratio (peripheral resistance) was calculated as the mean pressure in the brachial artery expressed in $\mathrm{mm}$. $\mathrm{Hg}$ divided by the cardiac output expressed in $1 . / \mathrm{min}$.

The patients breathed oxygen delivered at $10 \mathrm{l} / \mathrm{min}$. into a lightweight plastic face mask (Polymask 330216-British Oxygen Co. Ltd.). Approximately 40 per cent oxygen was inhaled by the patient. Before hæmodynamic measurements were made the patients had rested, breathing oxygen, for at least 20 minutes after the catheters had been inserted. Some had received oxygen from the time of admission to hospital. Duplicate determinations of cardiac output and repeated measurements of heart rate and blood pressure were made, a tap was then turned to allow compressed air from a cylinder to enter the mask at the same 
TABLE I

Clinical Data

\begin{tabular}{|c|c|c|c|c|c|c|c|c|c|}
\hline $\begin{array}{c}\text { Patient } \\
\text { No. }\end{array}$ & $\begin{array}{l}\text { Age } \\
\text { (yr.) }\end{array}$ & $\begin{array}{c}\text { Weight } \\
\text { (kg.) }\end{array}$ & $\begin{array}{c}\text { Height } \\
\text { (cm.) }\end{array}$ & Past history & $\begin{array}{l}\text { Presenting } \\
\text { symptom }\end{array}$ & $\begin{array}{l}\text { General } \\
\text { condition on } \\
\text { admission }\end{array}$ & $\begin{array}{l}\text { Highest } \\
\text { enzyme }\end{array}$ & E.C.G. & $\begin{array}{l}\text { X-ray appearance } \\
\text { of lung fields }\end{array}$ \\
\hline 1 & 64 & 72 & 169 & $\begin{array}{l}\text { Diabetes } \\
\text { mellitus } 15 \\
\text { years }\end{array}$ & $\begin{array}{l}\text { Sudden pain } \\
\text { across chest; } \\
\text { felt weak and } \\
\text { faint; vomited }\end{array}$ & $\begin{array}{l}\text { Pale and } \\
\text { sweating; } \\
\text { heart rate } \\
100 ; \text { JVP not } \\
\text { raised; BP } \\
115 / 70 \mathrm{~mm} \text {. } \\
\text { Hg; normal } \\
\text { heart sounds }\end{array}$ & $\begin{array}{l}\text { S-GOT* } \\
102 \\
\text { I.U. }\end{array}$ & $\begin{array}{l}\text { Sinus rhythm, } \\
\text { S-T segment } \\
\text { elevation in } \\
\text { aVF and III }\end{array}$ & Normal \\
\hline 2 & 72 & 65 & 162 & $\begin{array}{c}\text { Myocardial } \\
\text { infarction } \\
4 \text { years } \\
\text { previously }\end{array}$ & $\begin{array}{l}\text { Sudden loss of } \\
\text { consciousness; } \\
\text { recovered; } \\
\text { vomited; no } \\
\text { pain }\end{array}$ & $\begin{array}{l}\text { Pale; heart rate } \\
80 ; \text { JVP not } \\
\text { raised; BP } \\
145 / 75 \text { mm. } \\
\text { Hg; apex beat } \\
\text { displaced } \\
\text { laterally; } \\
\text { normal heart } \\
\text { sounds; râles } \\
\text { at lung bases }\end{array}$ & $\begin{array}{c}\text { S-GOT } \\
6 \text { I.U. }\end{array}$ & $\begin{array}{l}\text { Sinus rhythm, } \\
\text { S-T segment } \\
\text { elevation in } \\
\text { V2 to V7 }\end{array}$ & $\begin{array}{l}\text { Slight congestive } \\
\text { changes at } \\
\text { bases }\end{array}$ \\
\hline 3 & 73 & 64 & 160 & Effort angina & $\begin{array}{l}\text { Awoke in } \\
\text { morning with } \\
\text { severe chest } \\
\text { pain extending } \\
\text { down both } \\
\text { arms; weak } \\
\text { and } \\
\text { nauseated }\end{array}$ & $\begin{array}{l}\text { Pale and in } \\
\text { pain; heart } \\
\text { rate } 50 ; \mathrm{JVP} \\
+3 \mathrm{~cm} \text {; BP } \\
140 / 80 \mathrm{~mm} . \\
\text { Hg; apex } \\
\text { beat displaced } \\
\text { laterally; } \\
\text { presystolic } \\
\text { heart sound }\end{array}$ & $\begin{array}{l}\text { S-GOT } \\
22 \text { I.U. }\end{array}$ & $\begin{array}{l}\text { Sinus rhythm, } \\
\text { S-T segment } \\
\text { elevation in } \\
\text { aVF and III }\end{array}$ & $\begin{array}{l}\text { Slightly full } \\
\text { hilar shadows }\end{array}$ \\
\hline 4 & 47 & 76 & $176 \cdot 5$ & $\begin{array}{l}\text { Hypertension } \\
\text { many years; } \\
\text { effort angina } \\
1 \text { month }\end{array}$ & $\begin{array}{l}\text { Sudden severe } \\
\text { chest pain in } \\
\text { night; } \\
\text { vomited }\end{array}$ & $\begin{array}{l}\text { Good general } \\
\text { appearance; } \\
\text { heart rate } 60 ; \\
\text { JVP not raised } \\
\text { BP } 150 / 105 \\
\text { mm. Hg; } \\
\text { presystolic } \\
\text { heart sound }\end{array}$ & $\begin{array}{l}\text { S-GOT } \\
27 \text { I.U. }\end{array}$ & $\begin{array}{l}\text { Sinus rhythm, } \\
\text { slight } S-T \\
\text { elevation in } \\
\text { V4 }\end{array}$ & Normal \\
\hline 5 & 51 & 65 & 163 & Angina $3 \mathrm{mth}$. & $\begin{array}{l}\text { Collapsed while } \\
\text { bicycling; } \\
\text { severe pain; } \\
\text { ventricular } \\
\text { fibrillation in } \\
\text { hospital; } \\
\text { resuscitated }\end{array}$ & $\begin{array}{l}\text { Pale, sweating; } \\
\text { no pain after } \\
\text { resuscitation; } \\
\text { heart rate } 80 ; \\
\text { BP } 55 / 0 \text { rising } \\
\text { to } 100 / 60 \\
\text { mm. Hg } \\
\text { after } 2 \text { hours }\end{array}$ & $\begin{array}{c}\text { LDH† } \\
1230 \\
\text { I.U. }\end{array}$ & $\begin{array}{l}\text { Sinus rhythm, } \\
\text { S-T elevation } \\
\text { in V1-V4, } \\
\text { QT inversion } \\
\text { V4R-V4 }\end{array}$ & $\begin{array}{l}\text { Marked } \\
\text { pulmonary } \\
\text { œdema }\end{array}$ \\
\hline 6 & 56 & 78 & 177 & $\begin{array}{l}\text { Myocardial } \\
\text { infarction } \\
2 \text { weeks } \\
\text { previously; } \\
\text { acute } \\
\text { ventricular } \\
\text { fibrillation; } \\
\text { resuscitated }\end{array}$ & $\begin{array}{l}\text { Cardiac arrest; } \\
\text { resuscitated }\end{array}$ & $\begin{array}{l}\text { Very pale, } \\
\text { sweating; } \\
\text { peripherally } \\
\text { cyanosed; } \\
\text { heart rate } 60 \text {; } \\
\text { BP } 95 / 60 \\
\text { mm. Hg }\end{array}$ & $\begin{array}{l}\text { LDH } \\
1500 \\
\text { I.U. }\end{array}$ & $\begin{array}{l}\text { Q V2-V4; S-T } \\
\text { elevation } \\
\text { V2-V5; } \\
\text { T inversion } \\
\text { V2-V7 }\end{array}$ & $\begin{array}{l}\text { Marked } \\
\text { pulmonary } \\
\text { œdema }\end{array}$ \\
\hline
\end{tabular}

* Serum glutamic oxalacetate transaminase.

$\uparrow$ Serum lactic dehydrogenase.

rate as, and instead of, the oxygen. The change was made without the patient's knowledge. Measurements were made for $\mathbf{3 0}$ minutes after the change of gas. The exact times are given in Table II. On six occasions another set of measurements was made after a further change back to oxygen.

\section{RESULTS}

Table II gives hæmodynamic data recorded simultaneously with or just before each cardiac output determination. The percentage change given is based on average values of all measurements made while the patient was breathing air or oxygen respectively. The mean values given are restricted to the percentage change at the first investigation in each patient. The diagrams represent the measurements made immediately before the change of gas and the first measurement after the change. Given in the results are additional measurements of cardiac output and brachial arterial 


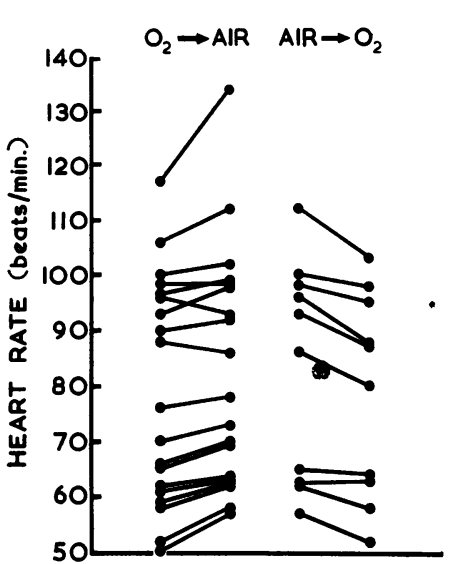

Fig. 1-Measurements of heart rate made before and after changing the inspired gas from oxygen to air and from air to oxygen.

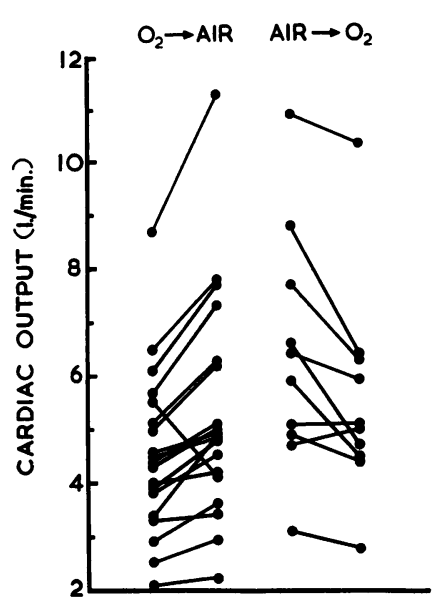

FIG. 2.-Measurements of cardiac output made before and after changing the inspired gas from oxygen to air and from air to oxygen.

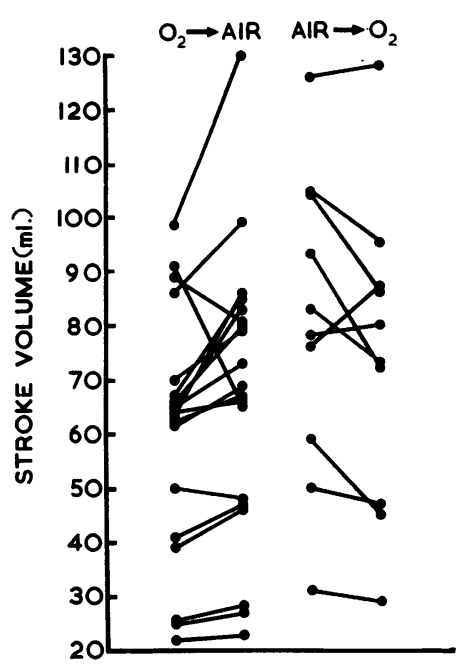

FIG. 3.-Stroke volume calculated from measurements of cardiac output and heart rate before and after changing the inspired gas from oxygen to air and from air to oxygen.

pressure made separately. These are not included in the detailed analysis as no evaluation of change in peripheral resistance was possible.

Heart Rate. When the patients were breathing air the heart rate ranged from 56 to 102 a minute in the 12 instances where the patients were in sinus rhythm. In one patient with atrial fibrillation the rate was 134 a minute. When the patients were breathing oxygen, the heart rate was lower in 16 of 19 comparisons (Table II). The mean of the differences in heart rate in the first comparison in each patient was 4 per cent.

In 9 additional instances in these patients and in one instance in another, comparisons were made. In 8 of these the heart rate was lower when the patients were breathing oxygen. Fig. 1 shows the last measurement before the change and the first measurement afterwards in 19 comparisons.

Cardiac Output. When patients were breathing air, cardiac output ranged from $2 \cdot 2$ to $7 \cdot 7$ 1./min.; breathing oxygen, the cardiac output was lower in 15 of 19 comparisons. The mean of the differences in the first comparison in each patient was 17 per cent $(p<0.01)$. Cardiac output change was measured on 9 additional occasions in these patients and in one instance in another patient with acute myocardial infarction. In all of these comparisons the cardiac output was lower when the patients were breathing oxygen. Fig. 2 shows the last measurement before the change and the first measurement after in 29 comparisons.

Stroke Volume. When patients were breathing air, the stroke volume ranged from 23 to $104 \mathrm{ml}$.; breathing oxygen, the stroke volume was lower in 14 of 19 instances. The mean of the differences in the first comparison in each patient was 14 per cent $(p<0.05)$. Stroke volume change was measured on 9 additional occasions in these patients and in one instance in another patient. In these comparisons stroke volume was lower when the patients were breathing oxygen in all but one instance. Fig. 3 shows the last measurement before the change and the first measurement after in 29 comparisons.

Brachial Artery Pressure. Systolic arterial pressure when patients were breathing oxygen ranged from 85 to $167 \mathrm{~mm}$. $\mathrm{Hg}$, diastolic pressure from 48 to $92 \mathrm{~mm}$. $\mathrm{Hg}$, and mean pressure from 61 to 122 $\mathrm{mm}$. Hg. When patients were breathing oxygen, systolic, diastolic, and mean pressures were higher in 14 of 19 comparisons. Fig. 4 shows an example of the pressure change recorded. The means of 
TABLE II $\stackrel{\mathbb{D}}{\rightleftharpoons}$

Hamodynamic Data of Patients with Acute Myocardial Infarction $c$.

\begin{tabular}{|c|c|c|c|c|c|c|c|c|c|c|c|c|c|}
\hline \multirow[t]{2}{*}{$\begin{array}{l}\text { Patient } \\
\text { No. }\end{array}$} & \multirow[t]{2}{*}{$\begin{array}{l}\text { Day of } \\
\text { infarction }\end{array}$} & \multicolumn{3}{|c|}{$\mathrm{Po}_{2}(\mathrm{~mm} . \mathrm{Hg})$} & \multicolumn{3}{|c|}{$\begin{array}{c}\text { Heart rate } \\
\text { (beats/min.) }\end{array}$} & \multicolumn{3}{|c|}{$\begin{array}{l}\text { Cardiac output } \\
(1 . / \mathrm{min} .)\end{array}$} & \multicolumn{3}{|c|}{$\begin{array}{l}\text { Stroke volume } \\
\text { (ml.) }\end{array}$} \\
\hline & & $\mathrm{O}_{2}$ & Air & $\mathrm{O}_{2}$ & $\mathrm{O}_{2}$ & Air & $\mathrm{O}_{2}$ & $\mathrm{O}_{2}$ & Air & $\mathbf{O}_{2}$ & $\mathrm{O}_{2}$ & Air & $\mathrm{O}_{2}$ \\
\hline \multirow[t]{2}{*}{1} & 1 & & & & $\begin{array}{l}78 \\
70\end{array}$ & $\begin{array}{l}73 \\
74\end{array}$ & & $\begin{array}{l}4 \cdot 2 \\
4 \cdot 5\end{array}$ & $\begin{array}{l}4 \cdot 8 \\
5 \cdot 0\end{array}$ & & $\begin{array}{l}54 \\
64\end{array}$ & $\begin{array}{l}66 \\
67\end{array}$ & \\
\hline & 2 & & & & $\begin{array}{l}68 \\
66\end{array}$ & $\begin{array}{l}70 \\
72\end{array}$ & & $\begin{array}{l}3 \cdot 6 \\
3 \cdot 3\end{array}$ & $\begin{array}{l}3 \cdot 4 \\
3 \cdot 3\end{array}$ & & $\begin{array}{l}52 \\
50\end{array}$ & $\begin{array}{l}48 \\
46\end{array}$ & \\
\hline \multirow[t]{3}{*}{2} & 1 & 234 & 60 & & $\begin{array}{l}78 \\
76\end{array}$ & $\begin{array}{l}78 \\
84\end{array}$ & & $\begin{array}{l}4 \cdot 8 \\
5 \cdot 0\end{array}$ & $\begin{array}{l}6 \cdot 2 \\
6 \cdot 1\end{array}$ & & $\begin{array}{l}61 \\
66\end{array}$ & $\begin{array}{l}80 \\
78\end{array}$ & \\
\hline & 2 & 155 & 60 & & $\begin{array}{l}66 \\
66\end{array}$ & $\begin{array}{l}70 \\
67 \\
65\end{array}$ & 64 & $\begin{array}{l}4 \cdot 1 \\
4 \cdot 3\end{array}$ & $\begin{array}{l}5 \cdot 1 \\
4 \cdot 8 \\
5 \cdot 1\end{array}$ & $5 \cdot 1$ & $\begin{array}{l}62 \\
65\end{array}$ & $\begin{array}{l}73 \\
72 \\
78\end{array}$ & 80 \\
\hline & 6 & & & & $\begin{array}{l}116 \\
117\end{array}$ & 134 & & $\begin{array}{l}2 \cdot 9 \\
2 \cdot 9\end{array}$ & $3 \cdot 6$ & & $\begin{array}{l}25 \\
25\end{array}$ & 27 & \\
\hline \multirow[t]{2}{*}{3} & 1 & 350 & 74 & & $\begin{array}{l}50 \\
52\end{array}$ & $\begin{array}{l}58 \\
56\end{array}$ & & $\begin{array}{l}3 \cdot 6 \\
3 \cdot 3\end{array}$ & $\begin{array}{l}5 \cdot 0 \\
5 \cdot 5\end{array}$ & & $\begin{array}{l}73 \\
63\end{array}$ & $\begin{array}{l}86 \\
98\end{array}$ & \\
\hline & 2 & 253 & 64. & 280 & $\begin{array}{l}57 \\
58\end{array}$ & $\begin{array}{l}62 \\
62\end{array}$ & $\begin{array}{l}58 \\
56\end{array}$ & $\begin{array}{l}4 \cdot 4 \\
3.9\end{array}$ & $\begin{array}{l}4.9 \\
4 \cdot 7\end{array}$ & $\begin{array}{r}5.0 \\
5.0\end{array}$ & $\begin{array}{l}78 \\
67\end{array}$ & $\begin{array}{l}80 \\
76\end{array}$ & $\begin{array}{l}87 \\
90\end{array}$ \\
\hline \multirow[t]{3}{*}{4} & 1 & & & & $\begin{array}{l}51 \\
50\end{array}$ & $\begin{array}{l}57 \\
57\end{array}$ & $\begin{array}{l}52 \\
55\end{array}$ & $\begin{array}{l}5 \cdot 0 \\
4 \cdot 5\end{array}$ & $\begin{array}{l}4.9 \\
5.9\end{array}$ & $\begin{array}{l}4 \cdot 5 \\
6 \cdot 2\end{array}$ & $\begin{array}{l}97 \\
91\end{array}$ & $\begin{array}{r}85 \\
104\end{array}$ & $\begin{array}{r}86 \\
113\end{array}$ \\
\hline & 2 & & & & $\begin{array}{l}55 \\
59\end{array}$ & $\begin{array}{l}62 \\
62\end{array}$ & $\begin{array}{l}62 \\
68\end{array}$ & $\begin{array}{l}4 \cdot 8 \\
5 \cdot 1\end{array}$ & $\begin{array}{l}6 \cdot 2 \\
6 \cdot 4\end{array}$ & $\begin{array}{l}5.9 \\
5 \cdot 8\end{array}$ & $\begin{array}{l}88 \\
86\end{array}$ & $\begin{array}{r}99 \\
104\end{array}$ & $\begin{array}{l}95 \\
85\end{array}$ \\
\hline & 2 & 395 & 79 & & $\begin{array}{l}59 \\
62\end{array}$ & $\begin{array}{l}63 \\
62\end{array}$ & & $\begin{array}{l}5 \cdot 1 \\
5 \cdot 5\end{array}$ & $\begin{array}{l}4 \cdot 1 \\
5 \cdot 6\end{array}$ & & $\begin{array}{l}87 \\
89\end{array}$ & $\begin{array}{l}65 \\
90\end{array}$ & \\
\hline 5 & 2 & & & & 96 & 93 & 87 & $6 \cdot 1$ & $7 \cdot 7$ & $6 \cdot 3$ & 64 & 83 & 73 \\
\hline \multirow[t]{2}{*}{6} & 1 & & & & 96 & 99 & & $2 \cdot 1$ & $2 \cdot 2$ & & 22 & 23 & \\
\hline & 2 & 270 & 59 & 202 & 100 & $\begin{array}{l}102 \\
100\end{array}$ & $\begin{array}{l}98 \\
99\end{array}$ & $2 \cdot 5$ & $\begin{array}{l}2 \cdot 9 \\
3 \cdot 1\end{array}$ & $\begin{array}{l}2 \cdot 8 \\
2 \cdot 8\end{array}$ & 25 & $\begin{array}{l}28 \\
31\end{array}$ & $\begin{array}{l}29 \\
28\end{array}$ \\
\hline
\end{tabular}

* These figures represent the time between changing the gas and making the measurements.

the differences in the first comparison were systolic 5 per cent, diastolic 3 per cent, and mean pressure 2 per cent. Additional measurements were made in four instances in one of the patients. On every occasion, systolic, diastolic, and mean pressures were higher when the patient was breathing oxygen. Fig. 5 shows the last measurement of the systolic and diastolic pressure before the change and the first measurement after in 23 comparisons. Fig. 6 shows the change in mean arterial pressure in these comparisons.

Peripheral Resistance. When patients were breathing air the peripheral resistance ranged from 9 to 33 units. When patients were breathing oxygen it was higher in 16 of 19 comparisons. The mean difference in the first comparisons was 25 per cent $(p<0.02)$. Fig. 7 gives the peripheral resistance calculated from measurements made before the change and from the first ones made after the change in 19 comparisons. 
When Breathing Oxygen and when Breathing Air

\begin{tabular}{|c|c|c|c|c|c|c|c|c|c|c|c|c|c|}
\hline \multicolumn{9}{|c|}{ Brachial arterial pressure $(\mathrm{mm} . \mathrm{Hg})$} & \multirow{2}{*}{\multicolumn{3}{|c|}{$\begin{array}{l}\text { Resistance } \\
\text { units }\end{array}$}} & \multirow{3}{*}{$\begin{array}{c}\text { Minutes } \\
\text { after change } \\
\text { to air* }\end{array}$} & \multirow{3}{*}{$\begin{array}{l}\text { Minutes } \\
\text { after change } \\
\text { to } \mathrm{O}_{2}^{*}\end{array}$} \\
\hline \multicolumn{3}{|c|}{ Systolic } & \multicolumn{3}{|c|}{ Diastolic } & \multicolumn{3}{|c|}{ Mean } & & & & & \\
\hline $\mathbf{O}_{2}$ & Air & $\mathrm{O}_{2}$ & $\mathrm{O}_{2}$ & Air & $\mathbf{O}_{2}$ & $\mathrm{O}_{2}$ & Air & $\mathbf{O}_{2}$ & $\mathbf{O}_{2}$ & Air & $\mathbf{O}_{2}$ & & \\
\hline $\begin{array}{l}142 \\
144\end{array}$ & $\begin{array}{l}137 \\
134\end{array}$ & & $\begin{array}{l}73 \\
74\end{array}$ & $\begin{array}{l}73 \\
64\end{array}$ & & $\begin{array}{l}100 \\
100\end{array}$ & $\begin{array}{l}95 \\
94\end{array}$ & & $\begin{array}{l}24 \\
22\end{array}$ & $\begin{array}{l}20 \\
19\end{array}$ & & $\begin{array}{l}10 \\
19\end{array}$ & \\
\hline $\begin{array}{l}105 \\
109\end{array}$ & $\begin{array}{l}103 \\
101\end{array}$ & & $\begin{array}{l}57 \\
58\end{array}$ & $\begin{array}{l}56 \\
57\end{array}$ & & $\begin{array}{l}73 \\
75\end{array}$ & $\begin{array}{l}72 \\
71\end{array}$ & & $\begin{array}{l}21 \\
23\end{array}$ & $\begin{array}{l}21 \\
21\end{array}$ & & $\begin{array}{l}10 \\
21\end{array}$ & \\
\hline $\begin{array}{l}127 \\
134\end{array}$ & $\begin{array}{l}137 \\
130\end{array}$ & & $\begin{array}{l}70 \\
74\end{array}$ & $\begin{array}{l}73 \\
72\end{array}$ & & $\begin{array}{l}90 \\
96\end{array}$ & $\begin{array}{l}95 \\
94\end{array}$ & & $\begin{array}{l}19 \\
19\end{array}$ & $\begin{array}{l}15 \\
16\end{array}$ & & $\begin{array}{l}14 \\
27\end{array}$ & \\
\hline $\begin{array}{l}138 \\
138\end{array}$ & $\begin{array}{l}142 \\
140 \\
135\end{array}$ & 143 & $\begin{array}{l}70 \\
73\end{array}$ & $\begin{array}{l}72 \\
72 \\
68\end{array}$ & 73 & $\begin{array}{l}88 \\
93\end{array}$ & $\begin{array}{l}96 \\
96 \\
92\end{array}$ & 98 & $\begin{array}{l}22 \\
22\end{array}$ & $\begin{array}{l}19 \\
20 \\
18\end{array}$ & 19 & $\begin{array}{l}16 \\
27 \\
34\end{array}$ & 23 \\
\hline $\begin{array}{r}94 \\
100\end{array}$ & $\begin{array}{l}87 \\
96\end{array}$ & & $\begin{array}{l}60 \\
59\end{array}$ & $\begin{array}{l}56 \\
57\end{array}$ & & $\begin{array}{l}72 \\
69\end{array}$ & 69 & & $\begin{array}{l}25 \\
24\end{array}$ & 19 & & 14 & \\
\hline $\begin{array}{l}153 \\
160\end{array}$ & $\begin{array}{l}141 \\
147\end{array}$ & & $\begin{array}{l}66 \\
70\end{array}$ & $\begin{array}{l}65 \\
65\end{array}$ & & $\begin{array}{r}96 \\
101\end{array}$ & $\begin{array}{l}92 \\
97\end{array}$ & & $\begin{array}{l}27 \\
31\end{array}$ & $\begin{array}{l}19 \\
18\end{array}$ & & $\begin{array}{l}16 \\
30\end{array}$ & \\
\hline $\begin{array}{l}143 \\
143\end{array}$ & $\begin{array}{l}130 \\
126\end{array}$ & $\begin{array}{l}141 \\
155\end{array}$ & $\begin{array}{l}65 \\
65\end{array}$ & $\begin{array}{l}59 \\
60\end{array}$ & $\begin{array}{l}64 \\
67\end{array}$ & $\begin{array}{l}95 \\
95\end{array}$ & $\begin{array}{l}86 \\
88\end{array}$ & $\begin{array}{l}92 \\
99\end{array}$ & $\begin{array}{l}22 \\
24\end{array}$ & $\begin{array}{l}17 \\
19\end{array}$ & $\begin{array}{l}18 \\
20\end{array}$ & $\begin{array}{l}23 \\
31\end{array}$ & $\begin{array}{l}18 \\
26\end{array}$ \\
\hline $\begin{array}{l}129 \\
132\end{array}$ & $\begin{array}{l}135 \\
134\end{array}$ & $\begin{array}{l}137 \\
143\end{array}$ & $\begin{array}{l}72 \\
72\end{array}$ & $\begin{array}{l}77 \\
78\end{array}$ & $\begin{array}{l}77 \\
80\end{array}$ & $\begin{array}{l}94 \\
95\end{array}$ & $\begin{array}{l}100 \\
102\end{array}$ & $\begin{array}{l}103 \\
104\end{array}$ & $\begin{array}{l}19 \\
21\end{array}$ & $\begin{array}{l}21 \\
17\end{array}$ & $\begin{array}{l}23 \\
17\end{array}$ & $\begin{array}{l}16 \\
34\end{array}$ & $\begin{array}{l}17 \\
28\end{array}$ \\
\hline $\begin{array}{l}151 \\
158\end{array}$ & $\begin{array}{l}167 \\
162\end{array}$ & $\begin{array}{l}180 \\
180\end{array}$ & $\begin{array}{l}84 \\
92\end{array}$ & $\begin{array}{l}92 \\
91\end{array}$ & $\begin{array}{l}98 \\
98\end{array}$ & $\begin{array}{l}110 \\
118\end{array}$ & $\begin{array}{l}122 \\
120\end{array}$ & $\begin{array}{l}130 \\
130\end{array}$ & $\begin{array}{l}24 \\
23\end{array}$ & $\begin{array}{l}20 \\
19\end{array}$ & $\begin{array}{l}22 \\
23\end{array}$ & $\begin{array}{l}18 \\
31\end{array}$ & $\begin{array}{l}20 \\
24\end{array}$ \\
\hline $\begin{array}{l}154 \\
155\end{array}$ & $\begin{array}{l}152 \\
150\end{array}$ & & $\begin{array}{l}83 \\
83\end{array}$ & $\begin{array}{l}83 \\
83\end{array}$ & & $\begin{array}{l}112 \\
111\end{array}$ & $\begin{array}{l}110 \\
109\end{array}$ & & $\begin{array}{l}22 \\
20\end{array}$ & $\begin{array}{l}27 \\
20\end{array}$ & & $\begin{array}{l}18 \\
26\end{array}$ & \\
\hline 107 & 99 & 100 & 53 & 48 & 50 & 70 & 68 & 69 & 12 & 9 & 11 & 9 & 10 \\
\hline 100 & 92 & & 68 & 65 & & 80 & 74 & & 38 & 33 & & 12 & \\
\hline 78 & $\begin{array}{l}86 \\
85\end{array}$ & $\begin{array}{r}98 \\
107\end{array}$ & 48 & $\begin{array}{l}55 \\
52\end{array}$ & $\begin{array}{l}57 \\
66\end{array}$ & 57 & $\begin{array}{l}64 \\
61\end{array}$ & $\begin{array}{l}66 \\
78\end{array}$ & 23 & $\begin{array}{l}22 \\
20\end{array}$ & $\begin{array}{l}23 \\
28\end{array}$ & $\begin{array}{r}9 \\
13\end{array}$ & $\begin{array}{r}6 \\
10\end{array}$ \\
\hline
\end{tabular}

\section{DisCUSSION}

Previous work on normal subjects (Barratt-Boyes and Wood, 1958; Daly and Bondurant, 1962), patients with pulmonary disease (Howarth, McMichael, and Sharpey-Schafer, 1947; Aber, Harris, and Bishop, 1964), with mitral stenosis (McGregor, Bothwell, Zion, and Bradlow, 1953), and with patent ductus arteriosus (Burchell, Swan, and Wood, 1953) has shown that the administration of oxygen has marked hæmodynamic effects. Circulatory changes following its administration in acute myocardial infarction had not been investigated. In this disease the basis for the use of oxygen as therapy is ill defined though heart muscle with borderline blood supply may benefit. Experimental work by Saÿen et al. (1951) in dogs demonstrated improved oxygenation in the peripheral zones of myocardial infarction when 100 per cent oxygen was delivered to the lungs. In addition to an effect 


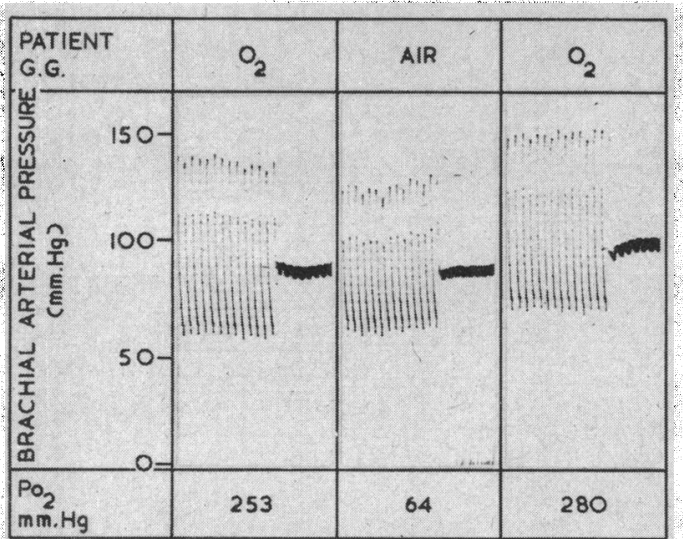

FIG. 4.-Brachial arterial pressure recorded while a patient was breathing oxygen, air, and after returning to oxygen. Arterial $\mathrm{Po}_{2}$ on each occasion shown below the appropriate trace. on damaged heart muscle, it might be anticipated that the somewhat increased oxygen saturation of hæmoglobin and the greatly increased oxygen tension in the blood might be of benefit if the circulation became inadequate for tissue metabolism as a whole.

We have shown that the administration of oxygen to patients with acute myocardial infarction results in a rise in arterial blood pressure and a fall in cardiac output. The component mechanisms involved in this response are not clear. It is probable that a rise of blood pressure in the presence of a lowered cardiac output is due to arterial vasoconstriction - either as a result of reflex activity or as a direct effect of oxygen. Direct vasoconstrictor effects of oxygen have been demonstrated by experimental work on animal preparations (Carrier and Guyton, 1963; Sobol et al., 1962). In man, breathing oxygen at high pressure has

been shown to reduce the calibre of retinal arteries and veins (Dollery et al., 1964). If the essential hæmodynamic response to oxygen administered to patients with acute myocardial infarction is vasoconstriction associated with an increase in blood pressure, the fall in cardiac output may be due to the rise in peripheral resistance.

The therapeutic implications of this work are not clear. The circulatory changes in acute myocardial infarction are complex; ideal therapeutic principles await definition and may be different in different patients. It is known that cardiac output can be within a wide range at a given low blood

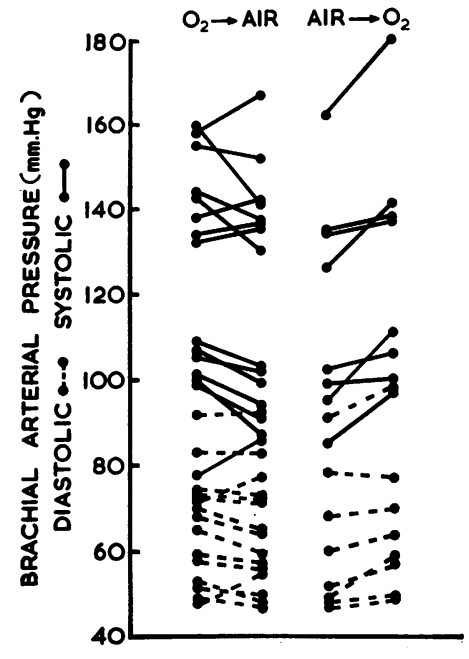

Fig. 5.-Measurements of brachial arterial systolic and diastolic pressure made before and after changing the inspired gas from oxygen to air and from air to oxygen.

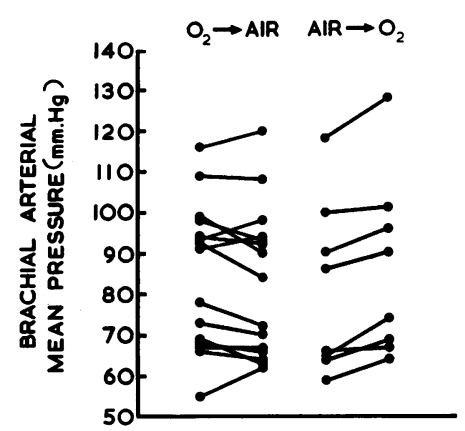

FIG. 6.-Measurements of brachial arterial mean pressure made before and after changing the inspired gas from oxygen to air and from air to oxygen.

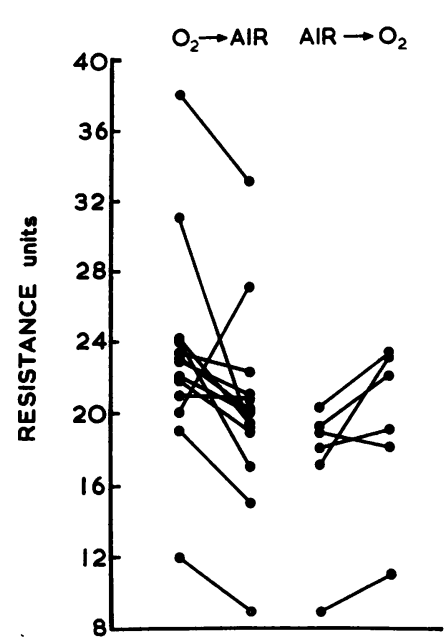

FIG. 7.-Peripheral resistance calculated from measurements of cardiac output and brachial arterial mean pressure made before and after changing the inspired gas from oxygen to air and from air to oxygen. 
pressure (Thomas, Malmcrona, and Shillingford, 1965) and a fall in cardiac output induced by oxygen administration could be of different significance in different patients. An analysis of potential benefit is made more difficult by ignorance of regional blood flow. Measurements in other conditions have shown that oxygen reduces cerebral flow in normal man (Kety and Schmidt, 1948) and reduces renal flow in patients with pulmonary disease (Aber et al., 1964). Oxygen has also been shown to lower pulmonary artery pressure in normal subjects (Barratt-Boyes and Wood, 1958) and in patients with mitral stenosis (McGregor et al., 1953). Further work including a study of the effects of oxygen on regional blood flow is necessary to define its place in therapy.

\section{SUMMARY}

The hæmodynamic changes following the administration of oxygen to patients with acute myocardial infarction have been studied. Measurements of cardiac output and brachial arterial pressure were made. Breathing 40 per cent oxygen usually results in a rise of systemic blood pressure and a fall in cardiac output. The possible mechanisms and clinical implications are discussed.

The authors wish to thank Mr. Peter Burgess and Miss Diana Cuttriss for technical assistance. They are indebted also to Sister T. Kirwan, Sister J. Child, and the Nursing Staff for the special co-operation and help which these investigations required. Miss J. Powell drew the diagrams.

\section{REFERENCES}

Aber, G. M., Harris, A. M., and Bishop, J. M. (1964). The effect of acute changes in inspired oxygen concentration on cardiac, respiratory and renal function in patients with chronic obstructive airways disease. Clin. Sci., 26, 133.

Barratt-Boyes, B. G., and Wood, E. H. (1958). Cardiac output and related measurements and pressure values in the right heart and associated vessels, together with an analysis of the hemodynamic response to the inhalation of high oxygen mixtures in healthy subjects. J. Lab. clin. Med., 51, 72.

Burchell, H. B., Swan, H. J. C., and Wood, E. H. (1953). Demonstration of differential effects on pulmonary and systemic arterial pressure by variation in oxygen content of inspired air in patients with patent ductus arteriosus and pulmonary hypertension. Circulation, 8, 681.

Carrier, O., and Guyton, A. C. (1963). Role of tissue oxygen in local autoregulation of blood flow. Circulation, 28, 701 (Abstr.).

Daly, W. J., and Bondurant, S. (1962). Effects of oxygen breathing on the heart rate, blood pressure, and cardiac index of normal men-resting, with reactive hyperemia, and after atropine. J. clin. Invest., 41, 126.

Dollery, C. T., Hill, D. W., Mailer, C. M., and Ramalho, P. S. (1964). High oxygen pressure and the retinal bloodvessels. Lancet, $2,291$.

Gabe, I. T., Tuckman, J., and Shillingford, J. P. (1962). Determination of relative changes in cardiac output from noncalibrated earpiece dye-dilution curves. Circulat. Res., 11, 405.

Howarth, S., McMichael, J., and Sharpey-Schafer, E. P. (1947). Effects of oxygen, venesection and digitalis in chronic heart failure from disease of the lungs. Clin. Sci., 6, 187.

Kety, S. S., and Schmidt, C. F. (1948). The effects of altered arterial tensions of carbon dioxide and oxygen on cerebral blood flow and cerebral oxygen consumption in normal young men. J. clin. Invest., 27, 484.

McGregor, M., Bothwell, T. H., Zion, M. M., and Bradlow, B. A. (1953). The effects of oxygen breathing on the pulmonary circulation in mitral stenosis. Amer. Heart J., 46, 187.

Saÿen, J. J., Sheldon, W. F., Horwitz, O., Kuo, P. T., Peirce, G., Zinsser, H. F., and Mead, J., Jr. (1951). Studies of coronary disease in the experimental animal. II. Polarographic determinations of local oxygen availability in the dog's left ventricle during coronary occlusion and pure oxygen breathing. J. clin. Invest., $30,932$.

Shillingford, J. P., and Thomas, M. (1964). The organization of a unit for the intensive care and investigation of patients with acute myocardial infarction. Lancet, $2,1113$.

Sobol, B. J., Wanlass, S. A., Joseph, E. B., and Azarshahy, I. (1962). Alteration of coronary blood flow in the dog by inhalation of $100 \%$ oxygen. Circulat. Res., 11, 797.

Thomas, M., Malmcrona, R., and Shillingford, J. P. (1965). Hæmodynamic changes in patients with acute myocardial infarction. Circulation. In the press. 